\title{
A NOTE ON THE CONSTITUTIONALITY OF STATE UNEMPLOYMENT COMPENSATION LAWS
}

\author{
LEON L. Rice, JR.*
}

The efficacy of the unemployment compensation titles of the Social Security Act ${ }^{1}$ is dependent upon the adoption by the states of legislation providing for such compensation, which will meet the standards prescribed by the federal statute. ${ }^{2}$ Either in anticipation of, or as a result of, the Federal Act, nine states and the District of Columbia have passed legislation for this purpose. ${ }^{3}$ With the enactment of similar bills in other states, ${ }^{4}$ the constitutional questions which they pose will become of nationwide importance. This note is concerned with the principal constitutional objections which will probably be raised to the state unemployment compensation acts which already have been or may be enacted in the near future. (The constitutionality of the Federal Act will be considered in the succeeding issue of this periodical.) Thus far, no state or federal court has passed on the validity of an unemployment compensation act. Judicial appraisal of the acts concerning matters peculiar to state constitutions will be in the hands of the highest tribunals of the several states. For final authority as to matters which involve rights guaranteed by the Federal Constitution we must await the decision of the United States Supreme Court.

* B.A., 1933, Furman University. President of the third year class in the Duke University School of Law. Associate Editor of the Duke Bar Association Journal.

${ }^{2}$ Act of Aug. 14, 1935, Public, No. 271, 74th Cong., Ist Sess., tit. III, IX, 42 U. S. C. A. \$\$301-1305.

${ }^{2}$ Employers throughout the United States subject to the Act are required to pay a payroll tax, effective January I, I936. Id., tit. IX, \$90r. To encourage and assist the states to pass unemployment compensation laws, it is provided that the taxpayer may credit against the federal tax contributions made under approved state laws, up to $90 \%$ of the federal assessment. Id., $\$ 902$. In addition, $\$ 4,000,000$ is appropriated for the fiscal year ending 1936, and \$49,000,000 each succeeding year, to be apportioned among the states having approved laws for administration expenses. Id., tit. III, \$301.

${ }^{3}$ The following laws have thus far been eracted: Alabama, Laws 1935, Scn. B. No. 395; California, Stat. 1935, c. 352; District of Columbia, Public, No. 386, 74th Cong., Ist Sess. (1935); Massachuselts, GeN. Laws, c. 151A (Laws 1935, c. 479); New Hampshire, Laws 1935, c. 99, as amended by c. I42; New York, Consol. Lnws, c. 31, art. 18, $\$ \$ 500-531$ (Laws 1935, c. 468); Oregon, Laws 1935, Spec. Sess., H. B. No. 71; Utah, Laws 1935, c. 38; Washington, Laws 1935, c. 145; Wisconsin, Wis. Stat. (1933) c. 108, as amended by Laws 1935, c. 192, 272, 446 .

A brief act was passed by North Carolina, Laws 1935, c. 492, which purports to authorize the Governor and Council of the State to set up a system of unemployment compensation "in the event of the enactment by the United States Congress of Unemployment Insurance Laws." No such system has in fact been set up under this act, and it will not be considered in this note.

- For a record of pending state bills, see C. C. H. UNEMP. INs. SERvice, 7021-7022. 


\section{Are Contributions Taxes?}

It is fairly safe to assume that the attack on the acts will be directed at the requirement that contributions be made by employers (and in some states employees) for the support of the compensation systems. The judicial approach will doubtless be first to determine whether the contributions are to be categorized as taxes or as exactions incidental to a scheme of regulation. If they are found to be taxes, various specific state constitutional provisions will be encountered, as well as the requirement that the levy be for a "public purpose," the due process, equal protection, and privileges and immunities clauses of the Federal Constitution. If, on the other hand, they are classified as regulatory devices, the principal problems will impinge upon the due process clause, with consideration also of the equal protection and privileges and immunities clauses. There will naturally be some degree of overlapping between the state and federal constitutions, in which case the federal construction should prevail.

All of the state statutes which have been enacted are compulsory, ${ }^{5}$ but they are not entirely uniform in character, ${ }^{6}$ A number of employments are excepted from each act. ${ }^{7}$ Otherwise, the general provision is that any employer who employs for a specified period of time within a year a specified number of persons or more, the "greater part" of whose work is done within the particular jurisdiction, is subject to its provisions. ${ }^{8}$ Employers within the acts are required to contribute a certain percentage of the total wages paid. ${ }^{9}$ Some of the acts, however, exempt employers who have established adequately secured guaranties of employment. ${ }^{10}$ Six provide for employee contributions as well."11 Seven ${ }^{12}$ follow the so-called "Ohio Plan,"13 and pool the contributions in a central fund. From this fund compensation is paid out to temporarily unemployed persons without regard to how much or little their

\footnotetext{
'Their compulsion lies in the requirement of contribution to unemployment compensation funds. True, some states allow employers to be exempted if they provide approved private compensation plans, see note 10, infra, yet this does not remove the element of compulsion, but only provides an alternative method.

${ }^{-}$Detailed studies of the state acts are to be found elsewhere in this symposium. For their texts, see C. C. H. Unemp. Ins. Service; Prentice-Hail Labor Law and Unemp. Ins. Service.

'The state acts usually follow the exemptions of the Federal Act, $\$ 907$ (c), with minor variations.

${ }^{8}$ The Federal Act taxes employers of eight or more, and five states follow this provision. Four states cover employers of four or more; the District of Columbia, of one or more. In indicating the territorial limits of coverage, California, District of Columbia, New Hampshire and Wisconsin acts have provisions in the language quoted above.

${ }^{\circ}$ The rate of contribution varies among the different states, beginning on a low scale for 1936, and ascending to the maximum during 1938 and thereafter, following, with some deviations, the ascending scale of the federal tax. Thus, the Alabama statute requires the employer to contribute $.9 \%$ of the payroll during $1936,1.8 \%$ during 1937 , and $2.7 \%$ during 1938 and thereafter. The District of Columbia requires employers subject to the act to pay $1 \%$ of the payroll into the fund in $1936,2 \%$ in $1937,3 \%$ for 1938 1940 , with a maximum during and after $194 \mathrm{I}$ of $4 \%$, and a minimum of $1.5 \%$.

${ }^{10}$ California, Massachusetts, and Wisconsin. The former two also exempt employers operating under other types of approved plans.

"Alabama, California, Massachusetts, New Flampshire, Oregon, and Washington.

${ }^{2}$ Alabama, California, District of Columbia, Massachusetts, New Hampshire, New York, and Washington.

${ }^{13}$ See Rubinow, State Pool Plans and Merit Rating, stura, p. 65.
} 
particular employer has paid into it. On the other hand, three of the statutes ${ }^{14}$ are patterned after the "Wisconsin Plan,"15 providing for separate reserve accounts for each employer-his employees being paid entirely out of his accumulated fund. With the exception of New York, ${ }^{16}$ every statute contains a system of "merit rating," which permits reductions in the amount of contributions, on the basis of contribution and benefit experience over a certain period of time. ${ }^{17} \mathrm{~A}$ minimum contribution rate is set by most of the acts. ${ }^{18}$ In accord with one of the requirements of the Social Security Act, the acts provide that the contributions are to be deposited to the credit of the depositing state with the Secretary of the Treasury of the United States. ${ }^{10}$ Administration is in the hands of boards or commissions already existent, or specially created for the purposes. ${ }^{20}$

- Are the compulsory contributions likely to be construed as taxes? ${ }^{21}$ The term "tax" has no well-defined meaning. Cooley's broad definition-"Taxes are the enforced proportional contributions from persons and property, levied by the state by virtue of its sovereignty for the support of the government and for all public needs." ${ }^{22}$-is of little help, for at least three other classes of governmental exactions have been distinguished. ${ }^{23}$ There is the "fee," which is an exaction for a special service rendered. ${ }^{24}$ A "penalty" is an enforced governmental contribution, which is designed to act as a deterrent to, or a punishment for, the commission of certain socially-undesirable acts. ${ }^{25}$ Finally, there is the "expropriation of money from one

st Oregon, Utah, and Wisconsin. Although following the employer reserve plan, Utah permits the administrative commission to compel pooling of funds in certain localities and industries.

${ }^{15}$ See Brandeis, The Employer Reserve Type of Unemployment Compensation Law, supra, p. 54.

${ }^{10}$ Its act directs an advisory council to study the feasibility of a merit-rating plan.

${ }^{17}$ Briefly, the system of merit rating is designed to equate as far as is practicable the amount of unemployment suffered in a particular employer's business with the amount of contributions made into the compensation fund. It will also serve to encourage the employer to keep his employment record as good as possible. See Rubinow, supra note 13, at pp. 79-86.

Is Wisconsin, however, allows contributions to cease if the individual employer's reserves reach $10 \%$ of his total payroll.

${ }^{10}$ Social Security Act, $\$ 903$ (a) (3). This provision promises to cause difficulties in states with constitutional provisions governing the deposit of state funds.

${ }^{20}$ See Cook, The Bodies Administering Unemployment Compensation Laws, supra, p. 95.

II It was tacitly assumed in a recent article that the contributions are excise taxes. See Epstein and Malisoff, Some Constitutional Obstacles to Unemployment Insurance (1935) 9 Socint SEcuntr, No. 9, p. 3. The Attorney General of Oregon in an opinion rendered on the constitutionality of the Oregon statute indicated this as a possible objection. C. H. H. UNEMP. INs. Senvice, 40-0r3-40,0 or 4.

${ }^{2}$ I COOLEY, TAXation (4th ed. I924) §I.

${ }^{23}$ The "special assessment," an exaction laid upon property levied according to the benefit conferred thereon, might also be distinguished. See id. $\$ 3 \mathrm{x}$.

${ }^{2}$ A common example is a sum assessed to pay the expenses of litigation, or for the filing and recording of certificates of capital stock. See id. \$33; Seligman, Essays on TAxation (roth cd. 1931) 407-413.

x The Child Labor Tax Case (Bailey v. Drexel Furniture Co.) 259 U. S. 20 (I922), is a classic example of a penalty in the guise of a tax. An act of Congress subjected employers of children in manufacturing establishments, etc., to an "excise tax equivalent to ten per centum of the entire net profits received or accrued for such year from the sale or disposition of the product" of such establishment, excepting employers acting under mistake and without intent to evade the tax. In holding the act to impose a penalty, Chief Justice Taft said: "Scienter is associated with penalties, not with taxes. . . . In the light 
group for the benefit of another ... to effectuate regulation of a matter in which both groups are interested, and in respect of which there is a power of legislative regulation."28 Obviously, the differentiation, between the conventional "tax," and the exaction of the third class, is difficult to draw. In an effort to determine the status of the contributions, resort must be had to analogies furnished by other types of legislation.

(I) Compulsory contributions to state workmen's compensation funds furnish perhaps the closest analogy. ${ }^{27}$ In very few cases in which the validity of the workmen's compensation acts was considered were the exactions required looked upon as taxes. In State ex rel. Davis-Smith Co.v. Clausen ${ }^{28}$ the Supreme Court of Washington, upholding an act requiring contributions to a state fund, held the contribution a "license tax." In Hunter v. Colfax Consolidated Coal Co., the Iowa court was willing to assume "for the sake of argument" that the law imposed a tax. ${ }^{29}$ In a California case it was held that the provisions of an act requiring the employer of a workman killed having no dependents to pay $\$ 350$ into a state fund for the promotion of vocational education and rehabilitation of workmen, is a "tax." 30 And the exaction from employers in a Maryland act creating a miner's relief fund was denominated a "tax." 31

Against these stands the whole array of decisions involving other workmen's compensation acts in which it was not even suggested that the payments might be considered taxes. In Sayles $v$. Foley ${ }^{32}$ the Rhode Island court dismissed as irrelevant cases having to do with taxes. In a California case a judge denied that the act involved a tax. ${ }^{33}$ The United States Supreme Court in a leading case ${ }^{34}$ explicitly

of these features of the act, a court must be blind not to see that the so-called tax is imposed to stop the employment of children within the age limits prescribed." Id. at 37.

Perhaps the latest example is U. S. v. Constantine, 56 Sup. Ct. 223 (1935), invalidating a prohibitive federal "tax" on liquor dealers operating in violation of state laws.

" Quoting Mr. Justice Roberts" majority opinion in U. S. v. Butler, 56 Sup. Ct. 312 (1936), holding the Agricultural Adjustment Act processing tax invalid. He also said: "It is inaccurate and misleading to speak of the exaction from processors ... as a tax. . . A tax, in the general understanding of the term, and as used in the Constitution, signifies an exacting for the support of the government." In Rickert Rice Mills, Inc. v. Fontenot, decided Jan. 13, 1936, he further said of this tax: "The exaction [despite the amendment of the Act] still lacks the quality of a true tax."

${ }^{2 \pi}$ Both impose liability on the employer regardless of fault-one for compensation for injuries and death suffered in the course of the employment; the other for injuries suffered from lack of employment. Both seek to shift a risk to the business. Both impose new liabilities. And both look primarily to the protection of the employec. This analogy has been suggested by current law review writers. See Legis. (1935) 35 CoL. L. REv. 1262, I266, n. 25; (1935) 4 Ford L. REv. 485, 495-496; (1935) Io ST. JOHN's L. REv. I 47, 154-155. However, many of these acts permit employers to remain outside the state system, subject to certain disabilities.

${ }^{\infty} 65$ Wash. 156, iry Pac. rior (x9ri).

${ }^{20}$ I75 Iowa 245, 297, 154 N. W. 1037, I056 (1915).

${ }^{20}$ Yosemite Lumber Co. v. Ind. Accid. Comm., I87 Cal. 774, 204 Pac. 226 (1922).

"Am. Coal Co. v. Allegheny County, 128 Md. 564, 98 Atl. I43 (1916).

38 R. I. 484, 490, 96 Atl. 340,343 (1916).

" Henshaw, J., dissenting (the majority had not suggested that the contributions were taxes). Western Indemnity Co. v. Pillsbury, 170 Cal. 686, I5I Pac. 398 (1915).

"Mountain Timber Co. v. Washington, 243 U. S. 219 (1917). 
refused to consider whether the Washington act involved a tax or a regulation under the state's police power. It is significant that in practically all workmen's compensation cases the acts are spoken of as an exercise of the police power rather than of the taxing power.

(2) In Noble State Bank v. Haskell, ${ }^{35}$ the Supreme Court upheld an Oklahoma statute which levied upon every bank in the state an assessment of a certain percentage of the deposits, for the purpose of creating a common guaranty fund. Mr. Justice Holmes, speaking for the unanimous Court, said: ". . . it would seem that there may be other cases beside the every day one of taxation, in which the share of each party in the benefit of a scheme of mutual protection is sufficient compensation for the correlative burden that it is compelled to assume. At least, if we have a case within the reasonable exercise of the police power, as above explained, no more need be said." 36 Those who attacked the act claimed that it was not an exercise of the taxing power. ${ }^{37}$

(3) Another analogy which should be of much persuasive force is the recent decision of the Supreme Court in the Railroad Pension Case. ${ }^{38}$ An act of Congress established a compulsory retirement and pension system for the employees of all railroad carriers in interstate commerce. The fund for the pensions was to arise from compulsory contributions from the carriers and their employees, to be deposited in the United States Treasury. In holding the act unconstitutional as violative of due process and beyond Congress' power to regulate commerce between the states, the Court did not suggest that the contributions required might be classified as taxes.

Add to these precedents the fact that the acts are not in the form of revenue measures, that merit rating is inconsistent with the ordinary notion of a tax, that the funds are limited to the payment of benefit claims, and the probability is that the contributions will be considered a regulatory "expropriation of money from one group for the benefit of another," rather than taxes. ${ }^{30}$ Especially is this true of those statutes embodying the employer reserves system.

${ }_{219}$ U. S. 104 (19Ir). This analogy was discussed in Legis. (1935) 4 ForD. L. REv. 485, 496; (1935) IO ST. JoHN'S L. REv. I47, 155.

${ }^{38} 2 \times 9$ U. S. at III.

${ }^{27}$ Id. at 106.

${ }^{23}$ Railroad Retirement Board v. Alton R. Co., 55 Sup. Ct. 758 (1935).

${ }^{39}$ If the exaction imposed by Title IX of the Federal Act were held a tax (as it must be to fall within the powers of Congress), this holding would not necessarily conflict with decisions holding the state exactions to be regulatory. The federal statute takes the form and has more of the qualities of a revenue measure, in that all the money collected goes into the general Treasury of the United Statcs, and the money advanced for administration of the state acts under Title III is a certain sum bearing no direct relation to the money collected. Under the state laws, however, the money collected is immediately segregated for compensation payments only and not for the general governmental revenue. Morcover, the exactions under the state laws bear more of the earmarks of regulations, since the systems of merit rating are designed, at least in part, to encourage the employers so to conduct their businesses that they will have a good employment record. But cf. Social Security Act, $\$ \$ 909-910$.

Titles II and VIII of the Federal Act, establishing a national system of old-age insurance financed by a "tax" on employers and employees, presents a closer analogy to the state unemployment compensation laws in this respect than does Title IX. 


\section{Constitutional Issues if Contributions are held Taxes}

Assuming, however, that the compulsory contributions will be considered to be taxes, what constitutional objections will be encountered? There is the general requirement, now under the wing of the due process clause, that taxes must be expended for a public purpose. ${ }^{40}$ Although it is not at all clear what constitutes a "public purpose," it is fairly predictable that, upon analogy to the workmen's compensation acts, the expenditure of money for unemployment compensation meets this test. ${ }^{41}$ It tends to stabilize purchasing power and to prevent indigency with its consequent burden upon the public. On the other hand, it is true that benefits are payable without regard to the need of the recipient; indeed, the basis of benefit payments is such that irregularity in employment diminishes the right to benefits, while the claimant with a long record of uninterrupted employment behind him can, in some states, secure extra benefits for that very reason. Yet, in view of the almost universal prevalence of governmental unemployment compensation systems, a decision denying that such systems in this country fell within the broad category of "public purpose" would seem an anachronistic anomaly.

Other federal constitutional limitations do not jeopardize this legislation seriously. The state acts do not seem to contravene the due process clause, unless the merit rating provisions offend the due process clause by reason of defects in the procedure adopted, ${ }^{42}$ or deny "equal protection of the laws" as a result of unreasonable classification. ${ }^{43}$ Certainly these statutes do not impair "the obligation of contracts." 44 Neither the "privileges and immunities" clause of Article IV, Section 2, forbidding unreasonable discriminations by states against the citizens of other states ${ }^{45}$ or the "privileges or immunities" clause of the Fourteenth Amendment forbidding the abridgment of rights enjoyed by virtue of national citizenship ${ }^{46}$ seem likely to present problems unless, possibly, in the application of these acts to some interstate employment situations.

Provisions in state constitutions are more definite. It is quite common for them to provide that taxation must be "uniform," or "uniform on the same class of sub-

${ }^{10}$ Jones v. City of Portland, 245 U. S. 217 (I9I7); I Cooley, TAXation \$174.

"Cooley says: "Workmen's compensation acts, if they be deemed to impose a tax, do so for a public purpose. ..." I CooLey, TAxation \$212. In Mountain Timber Co. v. Washington, szpra note 34, although it was not decided whether the contributions were taxes or regulations, it was held that the workmen's compensation act there in question was for a public purpose. "This decision defies the orthodox categories," it has been said in a leading article on this subject. "Whether this compulsory contribution be called a tax or an imposition the most we can say is that it is unobjectionable under the Fourteenth Amendment." McAllister, Public Purpose in Taxation (1930) 18 CALIF. L. Rev. 137, 249. Cf. Lewis \& Clark County v. Ind. Accid. Board, 52 Mont. 6, I55 Pac. 268 (19r6) (county tax levy to pay compensation to injured county employees held for a public purpose).

LHagar v. Reclamation Dist., III U.S. 701 (1884).

"But "the Fourteenth Amendment was not intended to compel the state to adopt an iron rule of equal taxation." Bell's Gap R. Co. v. Pennsylvania, I34 U. S. 232, 237 (I890).

"Kehrer v. Stewart, I97 U. S. 60 (I905).

43 I COOLEX, TAXation $\$ 250$.

${ }^{40}$ Colgate v. Harvey, 56 Sup. Ct. 252 (1935). 
jects." ${ }^{37}$ Some states apply this requirement to all types of taxes. ${ }^{48}$ But by the weight of authority it refers only to poll or property taxes. ${ }^{40}$ In the Clausen case, supra, the Washington court said of the exaction under the workmen's compensation act: "But it is manifest that it is not a 'tax' in the sense that the word is used in the sections of the constitution to which reference is here made." the uniformity provision applies to property taxation only. Cooley points out that whether or not the uniformity provision applies to taxes other than property taxes is of little practical significance: "If it does apply, the tax must be uniform on all persons of the same class. If it does not apply, the legislatures may nevertheless classify vocations and impose a tax of different amounts upon the different occupations." Since the exaction under the unemployment compensation acts is more in the nature of an "occupation," "privilege," or "excise" tax, few, if any, states are likely to throw out the "tax" on this ground. Difficulty, however, might be caused by merit rating which leads to a classification within a class. This might prove fatal where the uniformity requirement is held to apply to taxes other than those on property. But there is respectable authority that a uniformity provision not only allows classification, but also a progressive rate within the class. ${ }^{52}$ One court has stated that state uniformity provisions are coincident with the due process and equal protection clauses of the Federal Constitution. ${ }^{53}$

The typical merit-rating provision which allows the administrative board to reduce contributions upon the basis of unemployment experience might be held invalid as a delegation to a subordinate body of the legislative power to change rates of taxation. However, the Tariff Act of 1922, which empowered the President to increase or decrease the duties fixed by the act when they failed to equalize the difference between foreign and domestic costs, was sustained in Hampton \& Co. v. United States. ${ }^{54}$ Also, in so far as merit rating operates to lower the existing rates, the field for administrative discretion is broadened. Action by a tax official under a statute which "grants the taxpayer the benefit of discretionary action" has been held by the Supreme Court not subject to judicial review. ${ }^{65}$ Upon familiar principles of

${ }^{4}$ See, e.g., Ariz. Const. art. IX, $\$ 1$; Det. Const. art. VIII, §I; Mich. Const. art. X, §3; Ohto Const. art. XII, \$2; VA. Const. art. XIII, \$168; see Epstein and MaLisoff, supra note 2x, for a collection of relevant state constitutional provisions.

${ }^{48}$ United Cigar Stores v. Stewart, II4 Ga. 724, 87 S. E. 1034 (I916); In re Watson, I7 S. D. 486,97 N. W. 463 (1903); Ex parte Jones, 38 Tex. Cr. 482,43 S. W. 513 (1897).

*3 American Smelting \& Refining Co. v. People, 204 U. S. 103 (1907); Chicago \& N. W. R. v. State, 128 Wis. 533, 108 N. W. 557 (1906); Note (193I) 7I A. L. R. 256, 262; I COOLEX, TAXation \$253.

${ }^{50} 65$ Wash. 156, 203; ri7 Pac. IIoI, III8 (1911).

5. I Cooley, Taxation \$269. See also In re Watson, supra note 48 ; cf. Penna. v. Girard Life Ins. Co., $305 \mathrm{~Pa} .558,158$ Atl. 262 (1932).

${ }^{53}$ In re McKennan's Estate, 25 S. D. 369 , 126 N. W. 611 (19ro); cf. Clark v. Titusville, 184 U. S. 329 (I902).

* Penna. v. Girard Life Ins. Co., supra note $5 \mathrm{r}$.

84 276 U. S. 394 (r928).

${ }^{\infty}$ Heiner v. Diamond Alkali Co., 288 U. S. 502 (1933). 
administrative law, those statutes which set the standards and terms upon which contributions are to be regulated are on safer constitutional ground. ${ }^{56}$

It has been urged that if the contributions are called excises, they may be excluded by some twenty-two state constitutions which enumerate the types of taxes which may be levied, without including this particular type. ${ }^{57}$ There is no magic in the name "excise," and whether the contributions will be so denominated under the state constitutions is a matter of individual constitutional construction. But if the constitution of a particular state will not permit the levying of this type of "tax," amendment would be essential.

As a consideration in favor of construing the contributions to be taxes, it is submitted that the "public purpose" for which money raised by taxation may be expended is broader than the "public welfare" which justifies regulation under the police power. It seems clearer that a state can tax an employer (and employees) for the support of the unemployed than that it can thus regulate the employer and his private business for the same purpose. Professor McAllister has observed: "it is now settled that a municipality may operate a coal yard. But does that make the business of distributing fuel such a public one that private yards may be regulated as public utilities or even may be granted the power of eminent domain? An affirmative answer does not necessarily follow." 58 Moreover, the objections to the pooling of contributions, discussed later, do not apply if contributions are classed as taxes.

\section{Constitutional Issues if Contributions are held Regulatory Exactions}

Regarded as part of a regulatory scheme, the contributions must meet the objection that they deprive employer and employee of liberty and property without due process of law in contravention of the Fourteenth Amendment. Just what limitations the due process clause imposes on state legislation is a much mooted question. Its application depends upon the facts of each particular case; its meaning is arrived at by a process of "inclusion and exclusion." "59 Professor Brown has deduced the following formula: ${ }^{60}$ (I) the object of the legislation must be permissible; (2) the means must have a substantial relation to the end; (3) fundamental rights must not be infringed; and (4) the law in question must not be arbitrary, unreasonable, or oppressive. From the generality of these criteria it is apparent that the due process clause becomes a "peg" upon which judges may hang their social, economic, and political philosophies, sustaining or throwing out legislation which they believe un-

\footnotetext{
so "It may be laid down as a general proposition that where a legislature enacts a specific rule for fixing a rate of taxation, by which rule the rate is mathematically deduced from facts and events occurring within the year and created without reference to the matter of that rate, there is no abdication of the Iegislative function, but, on the contrary, a direct legislative determination of the rate." Per Brewer, J., in Mich. Cent. R. Co. v. Powers, 201 U. S. 245, 297 (1906).

$\pi$ See Epstein and Malisoff, supra note 21.

${ }^{80}$ McAllister, supra note $4 \mathrm{I}$, at 253.

${ }^{\infty}$ Sec Davidson v. New Orleans, 96 U. S. 97, 104 (1897).

${ }^{\infty}$ Brown, Due Process of Law, Police Power, and the Supreme Court (1927) 40 Harv. L. Rev. 943, 953.
} 
sound or unfair. ${ }^{61}$ And this despite the frequent assertion that questions of policy are solely for legislative determination.

Whenever a regulatory statute of this character is attacked as violative of due process, it is inevitably defended as an exercise of the "police power." power which a state possesses to legislate for the public health, morals, safety, and general welfare. ${ }^{63}$ The police power has been called the least limitable of all powers of government; ${ }^{64}$ Holmes stated that it "extends to all great public needs." ${ }^{\text {"S }}$ Anyone attacking a state statute is confronted by a presumption of constitutionality, with the concomitant burden of proving invalidating facts. ${ }^{66}$

Supreme Court decisions bearing on the employment relation will indicate to some degree the extent to which employer and employee may be constitutionally deprived of "liberty" and "property." State statutes have been held valid which abolished the fellow servant rule; ${ }^{67}$ established an eight hour day for mines and smelters; ${ }^{88}$ forbade the cleaning of coal before weighing to determine the miner's wage base; ${ }^{69}$ required the assent of the employer and the employee's wife to a wage assignment; $;^{70}$ made employers absolutely liable for injury to children engaged in extra-hazardous occupations; ${ }^{71}$ required wages to be paid semi-monthly; ${ }^{72}$ established a compulsory workmen's compensation system. ${ }^{73}$ On the other hand the limits are suggested by cases overthrowing statutes establishing a sixty-hour week for bakeries; ${ }^{74}$ forbidding discharge of employees for labor union membership; ${ }^{75}$ establishing compulsory arbitration for wage disputes; ${ }^{76}$ setting minimum wages for women in various employments. ${ }^{77}$

The cases invalidating state statutes prescribing minimum wages for women in various employments rested on the authority of Adkins v. Children's Hospital, ${ }^{78}$ which held invalid an act of Congress similarly setting minimum wages for the District of Columbia. In the Adkins case (a 5-to-4 decision) the Court said: "It compels him [the employer] to pay at least the sum fixed in any event, because the

\footnotetext{
"See Maggs, The Constitution and the Recovery Legislation: The Rotles of Document, Doctrine, and Judges (I934) I U. of Crn. L. REv. 665, 666-674.

${ }^{\circledR}$ See Cousens, The Constitutional Background of Unemployment Insurance (1934) 20 VA. L. REv. 497.

${ }^{e}$ Mott, Due Process of LAw (I926) 300.

At Hall v. Geiger-Jones Co., 242 U. S. 539, 548 (I917); per McKenna, J.

* In Noble State Bank v. Haskell, supra note 35 , at I I I.

${ }^{\infty}$ O'Gorman and Young, Inc. v. Hartford Fire Ins. Co., 282 U. S. 25I (193r).

${ }^{67}$ Missouri Pac. R. Co. v. Mackey, I27 U. S. 205 (I888).

${ }^{e s}$ Holden v. Hardy, I69 U. S. 366 (I898).

${ }^{\infty}$ McLean v. Arkansas, 2 I r U. S. 539 (1909).

${ }^{70}$ Mutual Loan Co. v. Martell, 222 U. S. 225 (Igri).

${ }^{71}$ Sturges Mfg. Co. v. Beauchamp, 23 I U. S. 320 (1913).

22 Erie R. Co. v. Williams, 233 U. S. 685 (1914).

${ }^{73}$ Mountain Timber Co. v. Washington, supra note 34 .

${ }^{74}$ Lochner v. New York, Ig8 U. S. 45 (1905).

${ }^{75}$ Coppage v. Kansas, 236 U. S. I (I9I5).

${ }^{78}$ Chas. Wolff Packing Co. v. Kans. Ct. of Ind. Relations, 262 U. S. 522 (I923).

${ }^{7}$ Murphy v. Sardell, 269 U. S. 530 (r925); Donham v. West-Nelson Mfg. Co., 273 U. S. 657 (1927).

${ }^{78} 26 x$ U.S. 525 (1923).
} 
employee needs it, but requires no service of equivalent value from the employee. . . . To the extent that the sum fixed exceeds the services rendered, it amounts to a compulsory exaction from the employer for the support of a partially indigent person for whose condition there rests upon him no peculiar responsibility, and therefore, in effect, arbitrarily shifts to his shoulders a burden which, if it belongs to anybody, belongs to society as a whole."79 Such language may sound menacing to any system of unemployment compensation. But a possible ground of distinction is that the unemployment compensation acts do not interfere with the right of the employer and employee to bargain as to the wage scale. The social outlook manifested by the Court, however, is ominous, especially since four members of the majority in the Adkins case are still on the bench. ${ }^{80}$

The analogy between compulsory workmen's compensation acts and unemployment compensation acts has already been discussed. ${ }^{81}$ In upholding the former acts, courts have recognized that accidents are foreseeable consequences of the employment relation, and that it is a reasonable exercise of the police power to shift the losses to the business through the employer. Much the same can be said of the latter acts. If a state can force the employer to provide for one type of loss, it seems reasonable to assume that it can make him provide, at least to a limited degree, for the other. Admittedly, however, the unemployment acts go farther than the workmen's compensation statutes, in that the former impose an entirely new liability where none existed. Still the latter do impose a substantial new burden when they impose liability regardless of fault. 82

The unemployment compensation acts go beyond the workmen's compensation legislation in at least one more respect. Compensation for injuries, disease, or death under the latter can be secured only if they arose out of the employment. ${ }^{83}$ As defined by the cases, this means that there must be some causal connection between the employment and the resultant injury. ${ }^{84}$ For this reason, it might be argued, it is not unfair to place the cost on the employer. On the other hand, unemployment is not caused by the employment nor usually by the employer, but largely by factors beyond his control; and hence it is unfair to impose liability therefor on the employer. ${ }^{85}$ These arguments, however, are not without countervailing factors. Though an injury is compensable only if it is caused by the employment, in a great number of the cases the causes are beyond the employer's control, and he is made to pay regardless of the precautions he has taken. It is true, to some extent at least, that an employer can so conduct this business that accidental injuries incident thereto

${ }^{70} \mathrm{Id}$. at $557-558$.

${ }^{80}$ For a discussion of the adventitious circumstances as to the Court's personnel at the time the case was decided, see Powell, The Judiciality of Minimum-Wage Legislation (I924) 37 HaRv. L. REv. 545-552.

${ }^{81}$ See pp. I4I-I 43, supra.

${ }^{85}$ See Hughes, C. J., dissenting in the Railroad Retirement Case, 55 Sup. Ct. at 777.

${ }^{8}$ Cudahy Packing Co. v. Parramore, 263 U. S. $4 \times 8$ (I923).

${ }^{\infty} 1$ 1bid.

${ }^{*}$ This argument is advanced in Legis. (1935) 4 Ford L. REv. 384, 495. 
will be at a minimum. Likewise, to a lesser extent perhaps, he can so manage his business that he can reduce the necessity of laying off workers to a minimum. In so far as the latter is true, unemployment may be said to be caused by the employment.

Ultimately it thus becomes a matter of degree under the due process clause whether the Supreme Court will consider the imposition of this novel burden too arbitrary and capricious to stand the test of constitutionality.

Language in the majority opinion invalidating the recent Railroad Retirement $\mathrm{Act}^{86}$ may indicate that the provisions of those unemployment compensation statutes which pool the contributions are violative of due process. The four dissenting justices relied on, but the majority sought to distinguish, three leading cases in which the pooling principle had been upheld. Dayton-Goose Creek $R$. Co. v. United States, $^{87}$ upholding legislation which required carriers to contribute part of their excess earnings to a revolving fund to be used primarily for loans to carriers, was not in point, said the Court, for that act had to be administered so as to leave each carrier a reasonable return upon its property. Mountain Timber Co. v. Washington $^{88}$ sustaining a compulsory workmen's compensation act of the pooling type was declared inapplicable, for it definitely provided that no class should be liable for the depletion of the accident fund by reason of accidents happening in any other class and thereby sought to equate the burden according to the risk. Noble State Bank $v$. Haskell, ${ }^{89}$ holding valid an assessment on all state banks for the creation of a central depositor's guaranty fund, was distinguished on the ground that it was supported by an ulterior public advantage, and the fact that the share in a scheme of mutual benefit is sufficient compensation for the taking. The Court then said: "We conclude that the provisions of the [Railroad Retirement] act which disregard the private and separate ownership of the several respondents, treat them all as a single employer, and pool all their assets, regardless of their individual obligations and the varying conditions found in their respective enterprises, cannot be justified as consistent with due process." 90

The ground of distinction taken in the Mountain Timber Co. case affords some basis for sustaining the pooling principle as embodied in the unemployment compensation statutes, since the system of merit rating takes into account the experience of each employer's business, and seeks fairly to equate the contributions to the benefits paid.91 A possible answer to this argument is that the merit-rating system represents only a rough approximation to unemployment experience. ${ }^{92}$ Moreover, it does not

${ }^{30}$ Supra note 38 .

87263 U.S. 456 (1924).

${ }^{8}$ Supra note 35 .

Supra note 34 .

${ }^{\infty} 55$ Sup. Ct. at 767 .

${ }^{21}$ See Legis. (1935) 35 CoL. L. REv. 1262, at $1287 \mathrm{n}$. 122, in which the following pertinent language of the Mountain Timber Co. case is quoted: "As further rebutting the suggestion that the imposition is exorbitant or arbitrary, we should accept the declaration of intent that the fund shall ultimately become neither more nor less self-supporting, and that the rates are subject to future adjustment by the legislature and the classifications to rearrangement according to experience, as plain evidence of an intelligent effort to limit the burden to the requirement of each industry." $243 \mathrm{U}$. S. at 221.

${ }^{22}$ See Rubinow, State Pool Plans and Merit Rating, supra, at pp. 83, 84. 
take effect until after three or more years, and hence the "arbitrary" feature persists until that time. Yet the Court might well take into account that this interim is a necessary feature of the rating system, and be lenient toward it. Obviously, the acts containing the employer reserves feature present no difficulty on the score of pooling. An employer cannot object that the amount of his contribution is affected by the unemployment experience of other employers.

Another constitutional objection, which may be summarily disposed of, is that the unemployment compensation acts deny the equal protection of the laws. ${ }^{93}$ This familiar clause forbids unjust discrimination; it does not prohibit reasonable classification. ${ }^{94}$ The usual statement is that a classification is permissible provided it proceeds on a difference which has a reasonable relation to the object sought to be attained. ${ }^{95}$ To be unconstitutional, the classification must produce an inequality which is actually and palpably unreasonable and arbitrary. ${ }^{96}$ The fact that the statute does not extend to all cases that it might possibly reach is no valid objection. ${ }^{97}$

It does not appear that confining the legislation to employers and employees for the benefit of the unemployed is a palpably unreasonable classification. Nor is confining it to employers of a certain number or more. It was never successfully urged that equal protection was denied in the workmen's compensation cases, and no different result is to be expected in the unemployment compensation cases. Again, however, it should be noticed that this flexible clause permits the play of the individual judges' social and economic philosophies. "Equal protection and due process are handmaidens which help each other with their tasks. One may be doing less only because the other is doing more." 98

It is to be expected that other constitutional obstacles to unemployment compensation will be encountered when the courts come to pass upon its validity and, if the systems run this initial gauntlet, again in the course of their administration. Limitations of space have prevented any exhaustive treatment of the subject in this note. Attempt has been made only to survey its salient features.

\footnotetext{
* U. S. Const. AMEND. XIV.

as Buck v. Bell, 274 U. S. 200 (1927); Dillingham v. McLaughlin, 264 U. S. 370 (1924).

${ }^{\infty}$ Atchison, ctc. R. Co. v. Matthews, I74 U. S. 96, I05 (1899).

${ }^{\infty}$ Fidelity Mut. L. Assoc. v. Mettler, 185 U. S. 308, 325 (1902).

${ }^{77}$ James-Dickinson Farm Mtge. Co. v. Harry, 273 U. S. II9 (1927).

${ }^{58}$ See Powell, The Supreme Court and State Police Power, I922-1930 (1932) r8 VA. L. Rev. 597, 640.
} 